Acta vet. scand. $1967,8,71-75$.

From the Norsk Hydro's Institute for Cancer Research and the Norwegian Radium Hospital, Oslo, Norway.

\title{
LEVELS OF $\mathrm{Cs}^{137}$ \\ IN NORWEGIAN LAMB AND SHEEP 1964-1965
}

\author{
By \\ Kjell Madshus and Aksel Strømme $e^{\star}$ )
}

In two previous papers (Madshus et al., 12; Madshus \& Strøm$m e, 5)$ the present authors have published data concerning the $\mathrm{Cs}^{137}$ concentrations in fresh lamb's meat.

\section{MATERIAL AND METHODS}

During the late fall of 1964,26 samples, and in the late fall of 1965, 23 samples of fresh meat from 5-6 months old lambs were collected. The same was done with 24 samples of fresh meat from adult sheep in the late fall of 1965 . All samples were collected from public slaughterhouses, the locations of which are shown in Fig. 1.

As before, all the samples were taken from the same part of the animal, i.e. the semitendinous muscle. This is a precaution taken in order to obtain comparable samples, because the $\mathrm{Cs}^{137}$ concentration may vary from muscle to muscle in the same animal (Kummeneje, 2).

Each fresh meat sample weighed approximately $1 \mathrm{~kg}$ after the removal of bone and fat. The meat was cut and dried at $100^{\circ} \mathrm{C}$ for several hours after the addition of distilled water and up to $20 \% \mathrm{Na}_{2} \mathrm{CO}_{3}$. This mixture, in which the fatty acids and sodium combined to make a dry powder, was ground and then measured by $\gamma$-spectroscopic methods using an $\emptyset 21 / 2 " \times 3^{\prime \prime} \mathrm{NaI}$ (Tl) crystal and a multichannel "kicksorter". At these levels of concentration, the standard error in the $\mathrm{Cs}^{137}$ determination was generally considered to be less than $\pm 2 \%$.

*) Contract no. AT(30-1)-3364 with U.S. AEC. 


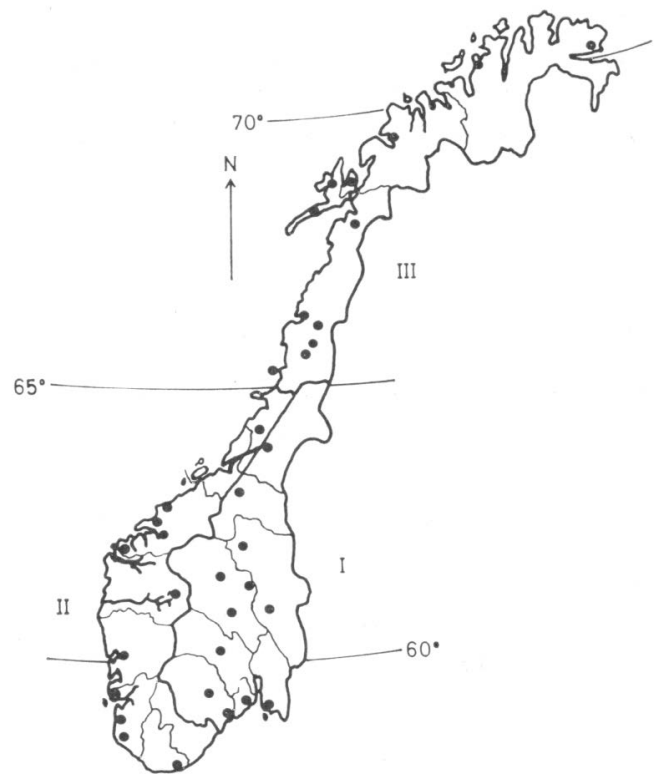

F i g u re 1. Map of Norway with the eighteen counties and the three zones. The location of the slaughterhouses.

\section{RESULTS AND DISCUSSION}

The single observations are presented in Table 1 . In a previous paper (9) the authors have shown that Norway can be divided into three zones in which statistically significant correlations between the precipitation one year and the $\mathrm{Cs}^{137}$ concentration in milk the following spring can be found. The same division into the three zones can apparently also be made with regard to cow's meat (4), potatoes (6), and carrots (7). These zones are shown in Fig. 1.

In Table 2 the mean, maximum and minimum concentrations of $\mathrm{Cs}^{137}$ in fresh meat samples taken from the three zones and the whole of Norway are presented. It is evident that no constant ratio between the $\mathrm{Cs}^{137}$ concentration in lamb's meat from the same slaughterhouse from fall 1964 to fall 1965 can be found. Similarly, no constant ratio can be found between the $\mathrm{Cs}^{137}$ concentration in meat from lamb and sheep taken from the same slaughterhouse during fall 1965.

Two points of interest can be noted from Table 2. The first is the high $\mathrm{Cs}^{137}$ concentration in meat from lamb as well as in meat from sheep, especially in Zone II and in Zone III. Milk has 
T a ble 1. The concentration of $\mathrm{Cs}^{137}$ in $\mathrm{nCi}$ per $\mathrm{kg}$ fresh meat from lamb, late fall 1964, lamb, late fall 1965, and sheep, late fall 1965.

\begin{tabular}{|c|c|c|c|}
\hline & Lamb 1964 & Lamb 1965 & Sheep 1965 \\
\hline \multicolumn{4}{|l|}{ Zone I: } \\
\hline Sarpsborg & 10.9 & 15.3 & - \\
\hline Tønsberg & 17.4 & 5.8 & 2.5 \\
\hline Hamar & 1.6 & 0.4 & 1.4 \\
\hline Gjøvik & - & 2.2 & 3.7 \\
\hline Otta & 2.3 & 0.8 & 1.0 \\
\hline Oppdal & 4.7 & - & 0.8 \\
\hline Steinkjer & 16.9 & 1.3 & 0.7 \\
\hline Gol & 2.9 & 2.8 & 1.6 \\
\hline Tynset & 3.2 & 2.9 & 1.2 \\
\hline Skien & 3.7 & 4.9 & 10.2 \\
\hline Lillehammer & 4.3 & - & - \\
\hline Notodden & 5.6 & - & - \\
\hline \multicolumn{4}{|l|}{ Zone II: } \\
\hline Kristiansand S. & 23.7 & 6.4 & 9.3 \\
\hline Sandnes & 13.4 & - & 0.8 \\
\hline Haugesund & 2.4 & 4.4 & - \\
\hline Sogndal & 6.6 & 0.4 & 3.5 \\
\hline Egersund & 14.5 & 18.3 & 2.6 \\
\hline Nordfjordeid & 5.4 & 15.5 & 3.6 \\
\hline Sunndals $\varnothing \mathrm{ra}$ & - & - & 10.6 \\
\hline Bergen & - & 15.8 & - \\
\hline Ålesund & 3.9 & - & - \\
\hline Kristiansand N. & 9.6 & - & - \\
\hline \multicolumn{4}{|l|}{ Zone III: } \\
\hline Vads $\phi$ & 4.5 & 2.7 & - \\
\hline Namsos & 7.4 & 4.0 & 14.9 \\
\hline Harstad & 5.2 & 7.0 & - \\
\hline Troms $\varnothing$ & - & - & 3.5 \\
\hline Mosjøen & 7.6 & 5.4 & - \\
\hline Bod $\varnothing$ & 10.7 & 4.9 & 5.1 \\
\hline Mo i Rana & 4.0 & 6.1 & 14.3 \\
\hline Brønnøysund & 8.7 & - & 12.3 \\
\hline Narvik & - & 8.3 & 4.1 \\
\hline Sortland & 一 & 10.1 & 2.3 \\
\hline Leknes i Lofoten & 14.7 & - & - \\
\hline Fauske & 13.3 & - & 3.3 \\
\hline
\end{tabular}

generally been considered (Anderson, 1) as being the source of about half the $\mathrm{Cs}^{137}$ body burden, but as shown by the present authors $(11,8,10)$, there are several groups of people for whom other parts of the diet are more important in this respect. This 
T a b le 2. The mean, maximum and minimum concentration of $\mathrm{Cs}^{137}$ in $\mathrm{nCi}$ per $\mathrm{kg}$ fresh meat from lamb 1964, lamb 1965 and sheep 1965.

\begin{tabular}{|c|c|c|c|c|c|c|c|c|c|}
\hline & \multicolumn{3}{|c|}{ Lamb 1964} & \multicolumn{3}{|c|}{ Lamb 1965} & \multicolumn{3}{|c|}{ Sheep 1965} \\
\hline & mean & $\max$. & $\min$. & mean & $\max$. & $\min$. & mean & $\max$. & min. \\
\hline Zone I & 6.7 & 16.9 & 1.6 & 4.0 & 15.3 & 0.4 & 2.6 & 10.2 & 0.7 \\
\hline Zone II & 9.9 & 23.7 & 2.4 & 10.1 & 18.3 & 0.4 & 5.1 & 10.6 & 0.8 \\
\hline Zone III & 8.5 & 14.7 & 4.0 & 6.1 & 10.1 & 2.7 & 7.5 & 14.9 & 2.3 \\
\hline All Norway & 8.2 & 23.7 & 4.0 & 6.3 & 18.3 & 0.4 & 4.9 & 14.9 & 0.7 \\
\hline
\end{tabular}

is, for instance, the case in several districts in Norway (3) where up to several pounds of meat from lamb or sheep are consumed by adult persons every week.

The next point of interest to be noted from Table 2 is the decrease of the $\mathrm{Cs}^{137}$ concentration in lamb's meat from 1964 to 1965, a decrease which coincides with the observed decrease of the average $\mathrm{Cs}^{137}$ body burden in man and the decrease of the average $\mathrm{Cs}^{137}$ concentrations in milk and other foodstuffs.

It may be noted, too, that the $\mathrm{Cs}^{137}$ concentrations in meat from lamb seem to be considerably higher than the $\mathrm{Cs}^{137}$ concentrations in meat from sheep, an observation which at present can not be accounted for.

\section{AGKNOWLEDGMENT}

This investigation has only been possible through the aid of veterinarian Ole S. Braathen at the "Norges Kjøtt- og Fleskesentral" whose kind cooperation in supplying the meat samples is highly appreciated.

\section{REFERENCES}

1. Anderson, E. C.: Radioactivity of people and milk: 1957. Science 1958, 128, 882.

2. Kummeneje, K.: Konsentrasjoner av Cesium-137 i kjøtt fra kjøttproduserende sjø- og landpattedyr i Norge i tidsrommet høsten 1961 til sommeren 1962. Internal Rep. F-0431. Norwegian Defence Research Establishment, Kjeller, 1962.

3. Madshus, $K$. \& A. Str $\phi$ mme: Radiocesium body burden in people from Masfjorden. Rep. to US AEC 3364-NYO-10.

4. Madshus, K. \& A. Strømme: Gamma spectroscopic investigations of cow's meat with regard to $\mathrm{Cs}^{137}$ caused by fallout in Norway. Rep. to US AEC 3364-NYO-12.

5. Madshus, K. \& A. Strømme: Radiocesium concentrations in Norwegian lamb and beef, late fall 1964. Rep. to US AEC 3364-NYO-13. 
6. Madshus, K. \& A. Strømme: $\mathrm{Cs}^{137}$ in potatoes in Norway, fall 1964. Rep. to US AEC 3364-NYO-15.

7. Madshus, K. \& A. Str $\emptyset$ mme: $\mathrm{Cs}^{137}$ in carrots in Norway, fall 1964. Rep. to US AEC 3364-NYO-16.

8. Madshus, K. \& A. Str $\phi m m e: \mathrm{Cs}^{137}$ body burden and its variation in 23 Norwegian school boys. Z. Naturforsch. 1964, Band $19 \mathrm{~b}$, Heft 11, 1055-1057.

9. Madshus, K. \& A. Strømme: Correlation between the precipitation and the amount of $\mathrm{Cs}^{137}$ in milk in Norway. Phys. in Med. Biol. 1965, 10, 529-538.

10. Madshus, K. \& A. Strømme: An investigation of a group of Norwegian school children with regard to body burden of $\mathrm{Cs}^{137}$ due to radioactive fallout. $Z$. Naturforsch. 1966, Band 21b, Heft 5, 440-442.

11. Madshus, K., A. Strømme \& K. Koren: Cæsium-137 body burden in persons chosen at random from selected areas in Norway. Nature (Lond.) 1963, 200, 278-279.

12. Madshus, K., A. Strømme \& K. Koren: Cesium-137 in milk, meat and man in Norway, 1962-1965. Radiological Health Data 1966, 7, 61-63.

\section{SUMMARY}

The concentrations of $\mathrm{Cs}^{137}$ in meat from lamb in the falls of 1964 and 1965 and in meat from sheep in the fall of 1965 have been determined. The results are given and discussed with regard to the geographical variations, the decreasing concentrations from 1964 to 1965 and to the different concentrations in lamb and sheep.

\section{ZUSAMMENFASSUNG}

Die Cs ${ }^{137}-M e n g e n$ in norwegischen Lämmern und Schafen.

Die Cs ${ }^{137}$-Konzentrationen in Fleisch von Lämmern und Schafen von der Ernte 1964 und der Ernte 1965 und in Fleisch von der Ernte 1965 sind bestimmt worden. Die Ergebnisse werden beschrieben und diskutiert in bezug auf die geographischen Variationen, die fallenden Konzentrationen von 1964 bis 1965 und in bezug auf die verschiedenen Konzentrationen in Lämmern und Schafen.

\section{SAMMENDRAG}

Cs $^{137}$ hos norske lam og sau.

Man har bestemt konsentrasjonen av Cs ${ }^{137}$ i kjøtt fra lam og sau fra høsten 1964 og høsten 1965 og i kjøtt fra høsten 1965. Resultatene er angitt og diskutert $\mathrm{m}$. h. til geografiske variasjoner, de avtagende konsentrasjoner fra 1964 til $1965 \mathrm{og} \mathrm{m}$. h. til de forskjellige konsentrasjoner i lam og sau. 